\title{
Groundwater quality appraisal and its hydrochemical characterization in and around Iron ore mine, Chitradurga, Karnataka
}

\begin{abstract}
The characterization of different parameters, factors, and mechanisms controlling the geochemistry of groundwater with the help of several hydrochemical indices and comparison study of data were the aim of this paper. The groundwater quality status in and around the M/s. A. Narrain Iron Ore Mine, Chitradurga District, Karnataka has been investigated in the present study. Groundwater samples were collected for one hydrological cycle and analyses for major ion chemistry. Minerals dissolution, chemical speciation and water-rock interaction during the process of percolation under low precipitation and high evaporation condition and mining activities are major causes behind the major ion contamination and deterioration of groundwater quality in the studied region. Therefore, it became essential to examine the suitability of groundwater around the iron ore mining area for drinking and irrigation purpose. Hydrogeochemical indices including water Quality Index (WQI), modified Piper diagram, Gibb's plot, Chloro-alkaline indices viz., CAI-I, CAI-II and SAR, RSC, KR ratio are used to assess the suitability of sample water for drinking, irrigation and domestic purpose. The analyses of CAI-I, CAI-II and SAR, RSC, KR hydrochemical indices confirm that groundwater of studied region is suitable for irrigation purpose. The analytical value of water quality index and comparison study of groundwater quality revealed approximately $60-70 \%$ samples exhibit poor water quality and slightly alkaline-fresh to brackish and chemically unsuitable for drinking purpose.
\end{abstract}

Volume I Issue 5 - 2017

Priyanka M, Venkata RG, Ratnakar D
CSIR-National Geophysical Research Institute, India

Correspondence: Priyanka M, CSIR-National Geophysical Research Institute, India, Email priyankamisra879@gmail.com

Received: October 04, 2017| Published: November 21, 2017

Keywords: CAI, Chloro Alkaline Indices; SAR, Sodium Absorption Ratio; RSC, Residual Sodium Carbonate; KR, Kelly's Ratio; GW, Ground Water; WQI, Water Quality Index

\section{Introduction}

Groundwater $(\mathrm{GW})$ is a significant freshwater resource for domestic, industrial and irrigation water supply in the India. During last decades, the demand of groundwater supply for drinking, domestic, irrigation, industrial and multipurpose uses has increased due to the rapidly rising population and constant desire for a better lifestyle in developing countries. Increasing demand for fresh water supply is exerting tremendous pressure on both surface and groundwater reserves which leads toward overexploitation and unsustainable groundwater development. Unsustainable groundwater development, overexploitation, and improper management of mining waste, wastewater from mining areas causes adverse impact on quality of groundwater., ${ }^{1,2}$ However, the quality of GW is also directly or indirectly influenced by the leaching of geogenic contaminants through mining site as a consequence of rock-water interaction during the process of percolation ${ }^{3}$ and when water moves through a hydrological cycle it transfers both inorganic and organic components from soil to water. Resulted, the higher concentration of ions in groundwater more than the acceptable limits of water quality standards ${ }^{4,5}$ which causes acute water-borne diseases in man and animals and also through food-chain. ${ }^{6,7}$ Therefore, the issues related to groundwater quality deterioration by anthropogenic activities are a pre-requisite for undertaking a detailed study on the groundwater geochemistry for restoring and maintaining its basic characteristics for which it is being explored. In Developing countries, mineral resources are significant sources for the economic development of the nation, but mineral development processes include exploration, extraction, and processing, are chief causes for poor groundwater quality in mining areas. ${ }^{8}$ Exploration, extraction, and processing of minerals on a large-scale generate a huge amount of mining waste has become an environmental concern and responsible for several types of damage and hazards including groundwater pollution. Chemical speciation, oxidation, and dissolution of chemical agents of major water-bearing rock formations (granite, gneiss) and minerals found in the studied area like silicates, carbonates, dolomite, and hematite, limestone, calcite and pyrite, are major factors governing migration of geogenic pollutant. ${ }^{910}$ It has been reported that mobility, bioavailability, and leaching of major ions are also significant factors affecting the quality of groundwater. However, valence state, atomic weight, ionic potential and composition of soil are most important factors affecting the mobility of cations in the aqueous phase. Since, elements with higher atomic weight like $\mathrm{Fe}, \mathrm{Cd}, \mathrm{Cr}$, and $\mathrm{Zn}$ have less mobility than major ions thus major ions are found in very high concentration than those of heavy metals. ${ }^{11}$ Soil with very less amount of clay and organic matter has very less sorption capacity and high mobility of ions from soil to groundwater. ${ }^{12-14}$ The hydrochemical processes like leaching of surficial salts, cation and anion exchanges, dissolution, precipitation and residential time all are major controlling factors for causing a change in the hydrochemical quality of groundwater of semi-arid and very dry areas having moisture indices less than minus $60 \% .^{15,16}$ The study on groundwater chemistry could reveal important information about geochemistry of groundwater, groundwater potential availability and the subsurface conditions of water-bearing 
rocks formations through which it is circulated. ${ }^{17-21}$ However, characterization of hydrochemical properties of groundwater depends upon the several other factors involving mobility, chemical speciation, and hydrology, general geology and lithology of area, degree of susceptibility of rock formations to chemical weathering, recharge water quality, quantity and nature of point and non-point sources rather than the dissolution and water-rock interaction. ${ }^{22-25}$ The aim of the present study to characterization of different parameters, factors and mechanism which controls the groundwater quality in and around the iron ore mine and to predict its suitability and acceptability for drinking, domestic and irrigation purposes. The assessment and prediction of groundwater quality around iron ore mine have done through analysis of several physico-chemical paramters and by adopting various methods and calculation of statistical variants like Water Quality Index, Gibbs plots, Chloroalkali indices (CAI) Sodium Absorption Ratio (SAR), Residual Sodium Carbonate (RSC) and Kelly's Ratio (KR). Comparision of analyzed data was made with the international and Indian standards. ${ }^{4,5}$

\section{Study area}

M/s. A. Narrain Iron Ore Mines of M/s. Vedanta Ltd. No. 2677 lies within $14^{\circ} 12^{\prime} 48.06^{\prime \prime}$ to $14^{\circ} 14^{\prime} 08.00^{\prime \prime} \mathrm{N}$ latitude and $76^{\circ} 11^{\prime} 49.94^{\prime \prime}$ to $76^{\circ} 12^{\prime} 54.93^{\prime \prime}$ E longitude with a total extent of 163.50 ha. The study area is located in between Megalahalli and Medakeripura villages of Chitradurga Taluk, Chitradurga District, Karnataka State with general ground elevation $891 \mathrm{~m}$ above MSL. The key map of the watershed covering M/s. A. Narrain Iron Ore Mine, Chitradurga is shown in Figure 1. The climatic condition of the studied area can be described as seasonally dry, which experiences a hot summer (temperature $40^{\circ} \mathrm{C}$ to $41^{\circ} \mathrm{C}$ ) and pleasant winter (temperature is around $14^{\circ} \mathrm{C}$ to $17^{\circ} \mathrm{C}$ ). It receives low to moderate rainfall and is one of the drought-prone districts in the state. The average annual rainfall in the mining area varies $668 \mathrm{~mm}$ to $457 \mathrm{~mm}$ reported by. ${ }^{26}$

\section{Geology and hydrology of the area}

The area of mine is a part of Niruthadi Reserve Forest area located in between the villages of Megalahalli and Medakeripura, trending NNW to SSE. Topographically, the terrain in which the mine area is situated belongs to Dharwar system. The presence of crystalline schists, granitic-gneisses and the newer granites with few intrusive dykes has been observed in major geological rock formations of the study region. The structural investigation of study region has shown its soil cover is composed of red lateritic soil rich with various minerals as well as hematite (iron ore). Groundwater in the study area occurs within the weathered and fractured rocks under semi-confined conditions. The groundwater depth to the water level of all observation well varies from $11.38 \mathrm{~m}$ to $39.47 \mathrm{~m}$ (bgl) during pre-monsoon season and from $8.88 \mathrm{~m}$ to $36.07 \mathrm{~m}(\mathrm{bgl})$ during post-monsoon season.

\section{Materials and methods}

Chemical analysis of water samples provides adequate information about qualitative and quantitative changes in groundwater systems which are useful to understand water quality conditions and effect of the composition of the material of aquifers and inputs of waters from various sources. The representative groundwater samples were collected in the vicinity of watershed covering of M/s. A. Narrain Iron Ore Mines for analyses of major ions during pre and post-monsoon period respectively. The location of collected samples is shown in Figure 1. The water samples were collected in polyethylene containers from 14 shallow and deep wells during pre and post-monsoon period.
The sampling containers were washed with distilled water prior to collection and then washed again with respective sample water before sampling and closed airtight. Likewise, all samples were collected. The chemical $\left(\mathrm{Na}^{+}, \mathrm{Ca}^{2+}, \mathrm{Mg}^{2+}, \mathrm{Cl}^{-}, \mathrm{F}^{-}, \mathrm{SO}_{4}^{2-}, \mathrm{HCO}_{3}^{-}, \mathrm{NO}_{3}^{-}\right)$and physical ( $\mathrm{pH}, \mathrm{TDS}, \mathrm{EC}$ ) parameters for water samples were analyzed in the laboratory using the standard methods suggested by. ${ }^{27}$ The $\mathrm{pH}$ was measured by using the digital $\mathrm{pH}$ meter. Electrical Conductivity and Total Dissolve Solids were estimated by the HANNA EC and TDS analyzer. Electrical Conductivity and Total Dissolve Solids and $\mathrm{pH}$ of water provide information about the thermodynamic state of water. ${ }^{27}$ Sodium and potassium ions were analyzed by flame photometry using CL-345 flame photometer of ELICO. Sulphate was estimated by the turbidity method using UV-Vis spectrophotometer at $425 \mathrm{~nm}$ wavelength. Fluoride was analyzed by colorimetric method using UV-Vis spectrophotometer at $570 \mathrm{~nm}$ wavelength. Nitrate was analyzed applying the spectrophotometric method using UVVis spectrophotometer at $220 \mathrm{~nm}$ wavelength. Standard titration methods were used to bicarbonate, calcium and chloride analysis. Furthermore, base-exchange indices $\left(r_{1}\right)$, meteoric genesis index $\left(r_{2}\right)$, Gibb's Plot, modified Piper diagram, Chloroalkali indices- (CAI-I and CAI-II) graphs used to determine the all factors which are altering the geochemistry of groundwater and aquifer components and to understand its suitability for irrigation and domestic use.

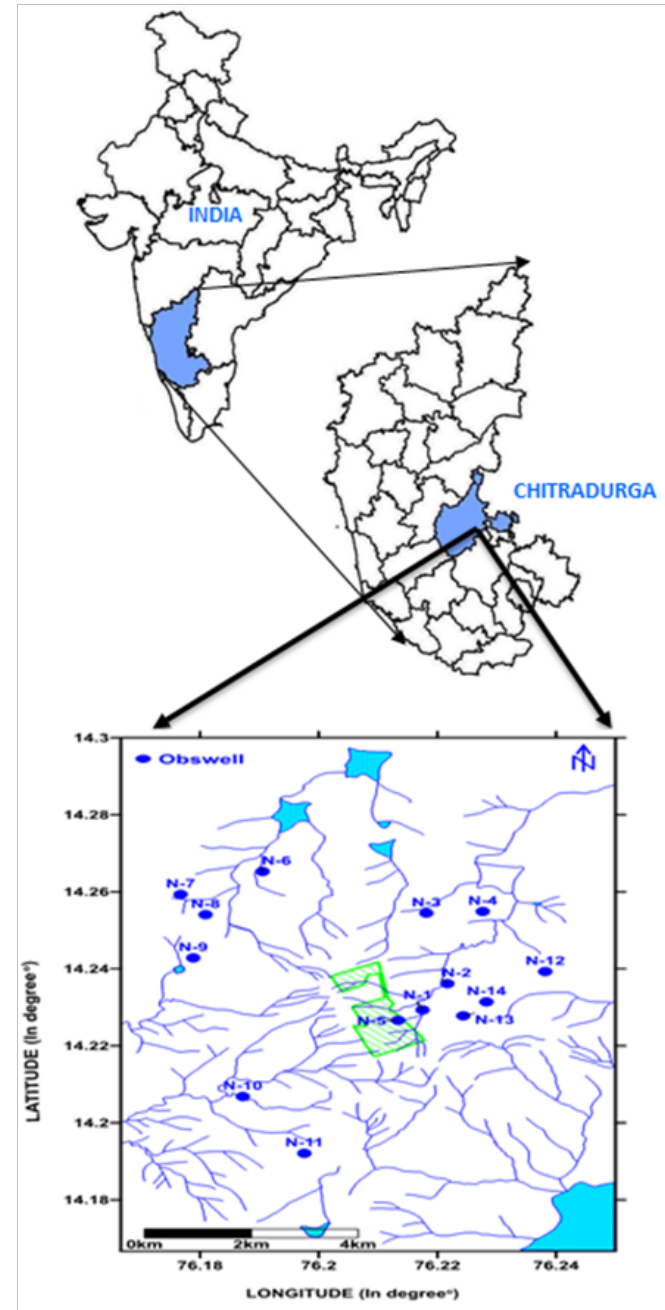

Figure I Key map of the study area showing Iron ore mine and sample locations. 


\section{Results and discussion}

\section{Drinking purposes}

Various physicochemical parameters such as $\mathrm{pH}, \mathrm{EC}, \mathrm{TDS}, \mathrm{Ca}$ $\mathrm{Mg}, \mathrm{Na}, \mathrm{K}, \mathrm{HCO}_{3}, \mathrm{SO}_{4}$, and $\mathrm{Cl}$ of the collected samples were analyzed by various statistical methods. All statistical variations, minimum, maximum, mean, median and standard deviation of variables for both pre and post-monsoon period is presented in Table 1. The $\mathrm{pH}$ values of groundwater samples varied between 6.8 to 7.9 and 6.85 to 8.5 during the pre-monsoon and post-monsoon seasons (Figure 2). The result shows that none of the water samples of pre and post-monsoon seasons exceeded the $\mathrm{pH}$ value of the ${ }^{4-28}$ standards and also falls within the standard limits cited by Saudi Arabian Standards Organization, ${ }^{29}$ and U.S Environmental Protection Agency. ${ }^{30}$ The mean $\mathrm{pH}$ value of pre and post-monsoon sample water are 7.2 to 7.5 respectively (Table 1). If the water sample has $\mathrm{pH}$ value more than 7.0 is considered as alkaline. It indicates the presence of a few cations and bicarbonate ions in groundwater. The combined amount of all dissolve cations and anions in the water is expressed as Total Dissolved Solids (TDS). It does not include suspended sediments, colloids and dissolved gases. TDS varies from $78 \mathrm{mg} / 1$ to $1521 \mathrm{mg} / \mathrm{l}$ in pre-monsoon and $126 \mathrm{mg} / \mathrm{l}$ to $900 \mathrm{mg} / \mathrm{l}$ in the post-monsoon period in the watershed around Iron Ore Mine (Figure 2). The mean value of TDS is $666.71 \mathrm{mg} / 1$ and $546.71 \mathrm{mg} / 1$ for pre-monsoon and post-monsoon period respectively (Table 1). The high content of TDS in water responsible for the salinity of water and influences the utility of water for different purposes. It represents most of the samples of the studied region are found undesirable for drinking purposes (Table 2). Sodium is an essential element to regulate blood pressure for normal nerve and muscle functions and to maintain the fluid balance in human body. Sodium concentration ranged from 12 to $75 \mathrm{mg} / 1$ during pre-monsoon period and 11 to $155 \mathrm{mg} / 1$ during the post-monsoon period (Figure 2)(Table 1). The mean value of sodium concentration varied from $38.21 \mathrm{mg} / 1$ to $65.19 \mathrm{mg} / \mathrm{l}$ in pre and post-monsoon period (Table 1). Higher concentration of salts may induce physiological changes in the consumer. It ranges in between standard values. ${ }^{4-28}$ Potassium is an essential element to regulate the metabolism in human being and to maintain the plant physiology. It varies from 08 to $10 \mathrm{mg} / \mathrm{l}$ in pre-monsoon samples and 1.4 to $12.2 \mathrm{mg} / 1$ in post-monsoon samples (Figure 2)(Table 1). Its elevated amount in drinking water effects on heart and kidney functions. Majority of samples have lower concentrations than standards value. ${ }^{4-28}$ Calcium and magnesium both are the most common divalent cation of sample water. Both are principal cations responsible for the water hardness. The observed calcium ion concentrations were ranged between 21 to $220 \mathrm{mg} / 1$ and 52 to $160 \mathrm{mg} / 1$ during pre and post-monsoon period respectively (Figure 2). Most of the groundwater samples have higher $\mathrm{Ca}^{+2}$ concentration than permissible limits of $>75 \mathrm{mg} / 1$ as $\mathrm{per}^{4-28}$ standards (Table1). Magnesium content varies from 24 to $112 \mathrm{mg} / 1$ and 2.25 to $83 \mathrm{mg} / \mathrm{l}$ in pre and post-monsoon period (Figure 2)(Table 1). The concentration of alkali metals in all water samples was higher during post-monsoon than pre-monsoon seasons. It may be because of areas lithology. The nitrate concentration in all samples of the studied region ranges from 98 to $517 \mathrm{mg} / 1$ and 1.24 to $125 \mathrm{mg} / \mathrm{l}$ in pre and post-monsoon seasons respectively (Figure 2)(Table 1). Undesirable nitrate concentration $>45 \mathrm{mg} / 1$ as per $^{4-28}$ standard was noted in approximately $100 \%$ pre-monsoon and $75 \%$ post-monsoon groundwater samples of the area (Figure 2). An abnormal concentration of nitrate in groundwater is resultant of the domestic wastewater discharge, and excessive fertilizer uses in or around the studied area. Higher concentration of nitrate in drinking water harmful to health causes blue baby syndrome. Bicarbonate concentration in both seasons' samples was found less than the permissible limit $500 \mathrm{mg} / 1$ specified by ${ }^{4-28}$ (Figure $2 \&$ Table 1). Hence, dilution of bicarbonate concentration by the rainfall recharge is obvious. Analytical result of $\mathrm{Cl}$ concentration shows that $80 \%$ water samples of post-monsoon seasons were found to be higher than those of pre-monsoon samples (Table 1)(Figure 2). Elevated $\mathrm{Cl}$ concentration has been observed in $25 \%$ post-monsoon samples are more than ${ }^{5}$ standard (Figure 2). Higher concentration of chloride produces a salty test in water. $\mathrm{Cl}$ contamination in arises in post-monsoon groundwater samples might be due to the local anthropogenic activities and runoff from agricultural areas after rainfall and discharge of human and animal waste in the studied area. Fluoride concentration ranged from 0.40 to $1.43 \mathrm{mg} / 1$ during pre-monsoon season and 0.73 to $2.27 \mathrm{mg} / 1$ during post-monsoon seasons (Figure 2)(Table 1). High Fluoride content was found in the groundwater of study area in post-monsoon seasons due to the breakdown and weathering of rocks such as granite and gneiss. Fluoride concentrations level between 0.8 and $1.0 \mathrm{mg} / 1$ is essential for preventing the tooth from decay. However, its higher concentration than $1.0 \mathrm{mg} / 1$ to $1.5 \mathrm{mg} / 1,{ }^{4-28}$ standard limit can cause skeletal fluorosis.

Table I Statistical summary of physic-chemical parameters determined in pre and post-monsoon groundwater samples of M/s. A. Narrain Iron Ore Mine, Chitradurga

\begin{tabular}{|c|c|c|c|c|c|c|c|c|c|c|c|}
\hline \multirow[t]{2}{*}{ Parameter } & \multirow{2}{*}{$\begin{array}{l}\text { Maximum permissible } \\
\text { limit in Mg/L (WHO) }\end{array}$} & \multicolumn{5}{|c|}{ Pre-monsoon } & \multicolumn{5}{|c|}{ Post-monsoon } \\
\hline & & Min & Max & Mean & Med & SD & Min & Max & Mean & Med & SD \\
\hline $\mathrm{pH}$ & 6.5 to 8.5 & 6.8 & 7.9 & 7.28 & 7.3 & 0.35 & 6.85 & 8.25 & 7.75 & 7.885 & 0.42 \\
\hline TDS & $500 \mathrm{mg} / \mathrm{l}$ & 78 & $|52|$ & 666.71 & 585 & 360.03 & 126 & 900 & 546.71 & 537 & 192.13 \\
\hline $\mathrm{Na}$ & $200 \mathrm{mg} / \mathrm{l}$ & 12 & 75 & 38.21 & 36.5 & $|4.5|$ & 11 & 155 & 65.19 & 65 & 35.47 \\
\hline K & $12 \mathrm{mg} / \mathrm{l}$ & 0.8 & 10.1 & 3.64 & 2.65 & 2.81 & 1.4 & 12.2 & 4.57 & 4 & 2.76 \\
\hline $\mathrm{Ca}$ & $75 \mathrm{mg} / \mathrm{l}$ & 21 & 220 & 101.21 & 103 & 49.27 & 52 & 160 & 100.86 & 100 & 29.23 \\
\hline $\mathrm{Mg}$ & $30 \mathrm{mg} / \mathrm{l}$ & 24 & 112 & 78.21 & 84.5 & 22.02 & 2.25 & 83 & 37.11 & 37.5 & 20.46 \\
\hline SO4 & $200 \mathrm{mg} / \mathrm{l}$ & 35 & 68 & 48.07 & 47.5 & 7.38 & 2.28 & 32.73 & 14.78 & 12.95 & 10.57 \\
\hline $\mathrm{NO} 3$ & $45 \mathrm{mg} / \mathrm{l}$ & 98 & 517 & 216.64 & 205.5 & 101.25 & 1.24 & 125 & 61.64 & 69 & 37.77 \\
\hline $\mathrm{HCO} 3$ & $500 \mathrm{mg} / \mathrm{l}$ & 73 & 468 & 321.07 & 353.5 & $|20.3|$ & 31 & 294 & I76.7| & 170 & 63.27 \\
\hline $\mathrm{Cl}$ & $250 \mathrm{mg} / \mathrm{l}$ & 17 & 333 & 91.93 & 74 & 79.5 & 18 & 327 & 140.86 & 145.5 & 79.15 \\
\hline $\mathrm{F}$ & $1.5 \mathrm{mg} / \mathrm{l}$ & 0.4 & $\mathrm{I} .43$ & 1.24 & 1.28 & 0.25 & 0.73 & 2.27 & 1.27 & 1.08 & 0.47 \\
\hline
\end{tabular}

Min, Minimum; Max, Maximum; Med, Median; SD, Standard Deviation 

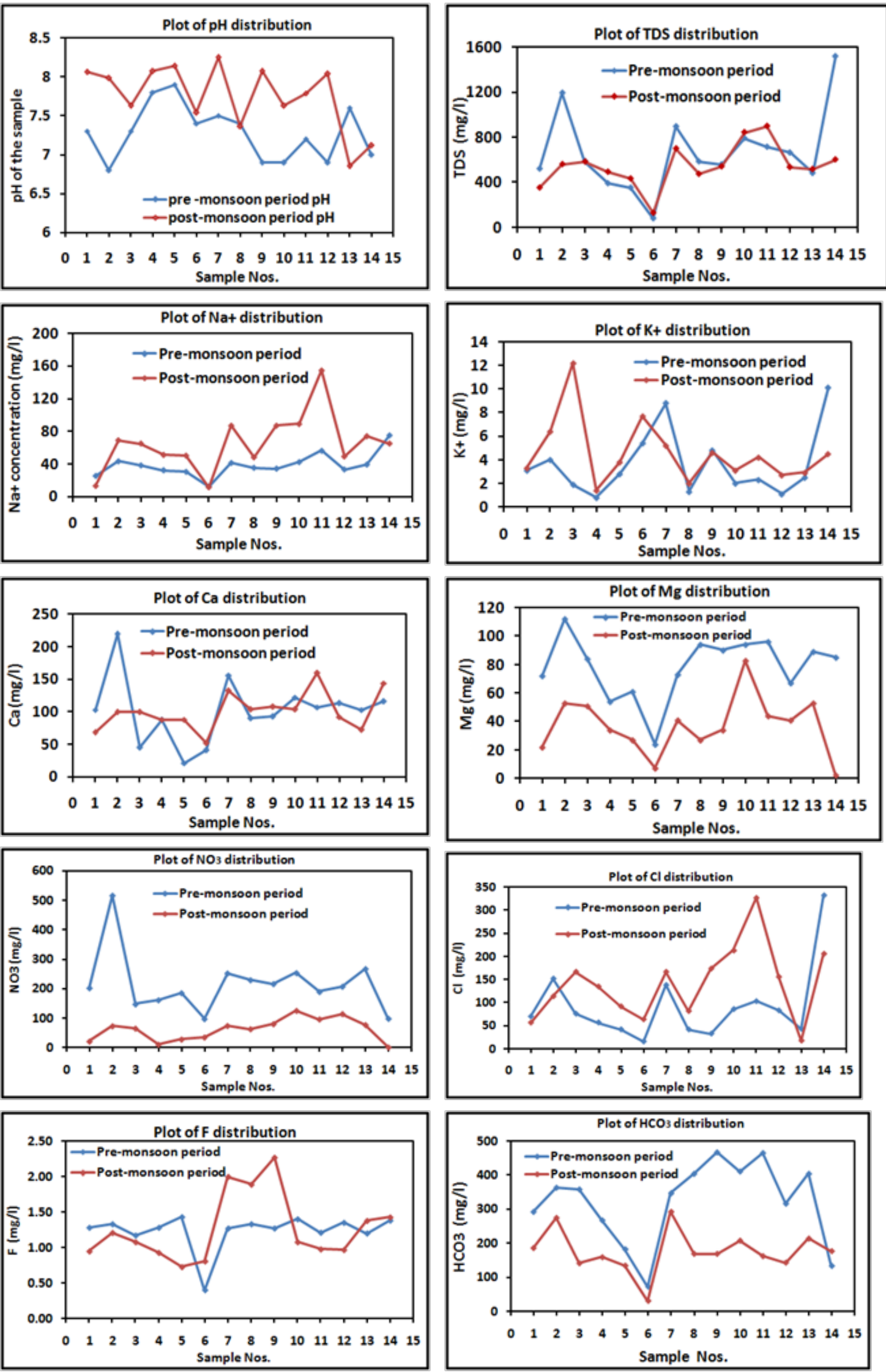

Figure 2 Plot of seasonal variations of various parameters.

Citation: Priyanka M,Venkata RG, Ratnakar D. Groundwater quality appraisal and its hydrochemical characterization in and around Iron ore mine, Chitradurga, Karnataka. Int J Hydro. 20 I7; I (5): I 5 I-I6I. DOI: I0.15406/ijh.20I7.0I.00029 
Table 2 Classification of ground water according to TDS value

\begin{tabular}{llll}
\hline Tds value & Class & \multicolumn{2}{l}{ Samples falling in dissimilar Seasons } \\
\cline { 3 - 4 }$(\mathbf{m g} / \mathbf{l})$ & & Pre-monsoon & Post-monsoon \\
\hline & & No. of samples N=I4 & No. of samples N=I4 \\
& & & \\
\hline 500 & fresh & $28 \%$ & $35 \%$ \\
$500-30,000$ & Brackish & $72 \%$ & $65 \%$ \\
\hline
\end{tabular}

\section{Water quality index}

Water quality index (WQI) of all water samples were calculated by the following expression..$^{31,32}$

$$
Q_{i}=100\left[\left(v_{i}-v_{o} / s_{i}-v_{o}\right)\right]
$$

$V_{i}$, Estimated value of the $i^{\text {th }}$ water quality parameters of collected sample

$\mathrm{Q}_{\mathrm{i}}$, Quality rating for the $\mathrm{i}^{\text {th }}$ water quality parameter

$S_{i}$, Standard permissible value of the $i^{\text {th }}$ water quality parameter (Table 3)

$\mathrm{V}_{0}$, Ideal value of the $\mathrm{i}^{\text {th }}$ water quality parameter in pure water (Table 3)

$W Q I=\sum Q_{i} W_{i} / \sum W_{i}$

$\mathrm{W}_{\mathrm{i}}$, Unit weight for $\mathrm{i}^{\text {th }}$ water quality parameter;

$W_{i}=K / s_{i}$

$\mathrm{K}$, Constant for proportionality

Table 3 Drinking water standards recommending agencies and ideal value for all parameters (all concentration values except pH are in $\mathrm{mg} /$ )

\begin{tabular}{llll}
\hline Parameter & Standards (Si) & Recommended agency & Ideal value (Vo) 32 \\
\hline $\mathrm{pH}$ & $6.5-8.5$ & BIS/WHO & 7 \\
Total Dissolved Solids (TDS) & 500 & BIS/WHO & 0 \\
Sodium (Na) & 200 & BIS & 0 \\
Potassium (K) & 12 & BIS & 0 \\
Fluoride (F) & 1.5 & BIS/WHO & 0 \\
Chloride (Cl) & 250 & BIS/WHO & 0 \\
Calcium (Ca) & 75 & BIS/WHO & 0 \\
Magnesium (Mg) & 30 & BIS & 0 \\
Sulphate (SO4) & 150 & BIS/WHO & 0 \\
Nitrate (NO3) & 45 & BIS/WHO & 0 \\
Bicarbonate (HCO3) & 200 & BIS/WHO & 0 \\
\hline
\end{tabular}

This index was developed by ${ }^{33}$ to determine the impact of the most common variables like $\mathrm{pH}$, Electrical Conductivity (EC), Total Dissolved Solids (TDS), and Total Hardness (TH), Bicarbonate $\left(\mathrm{HCO}_{3}\right)$, Calcium $(\mathrm{Ca})$, Magnesium $(\mathrm{Mg})$, Chloride $(\mathrm{Cl})$, Sodium $(\mathrm{Na})$, Fluoride $(\mathrm{F})$, Sulphate $\left(\mathrm{SO}_{4}\right)$ on water quality. ${ }^{34,35}$ Water quality rating based on WQI is described (Table 4). The analytical results of WQI of water samples are shown Table 5. The water quality rating of pre-monsoon sample water of study area is shown that $50 \%$ samples are unsuitable for drinking and other domestic use, while the rest $42 \%$ sample have very poor water quality (Table 5). $78 \%$ water samples collected during post-monsoon season fall in the category of very poor water quality rating. The complete analytical results (Table 5) are shown that groundwater samples of studied area are not suitable for drinking purpose.

\section{Irrigation water quality}

The base-exchange indices $r_{1}$ can be used to further classification of groundwater samples into two groups as $\mathrm{Na}^{+}-\mathrm{HCO}_{3}^{-}$type and $\mathrm{Na}^{+}-\mathrm{SO}_{4}^{2-}$ type by using the following Eq.1. If $\mathrm{r}_{1}$ value is $>1$ the groundwater samples will be categorized as $\mathrm{Na}^{+}-\mathrm{HCO}_{3}^{-}$type while $\mathrm{Na}^{+}-\mathrm{SO}_{4}^{2-}$ type if $\mathrm{r}_{1}<1 .{ }^{36}$

$$
r_{1}=\mathrm{Na}^{+}-\mathrm{Cl}^{-} / \mathrm{SO}_{4}{ }^{2-} \mathrm{meq} / \mathrm{l}
$$

Table 4 Water Quality Index (WQI) and rating of water quality

\begin{tabular}{ll}
\hline Wqi range & Water quality rating \\
\hline $0-25$ & Excellent water quality \\
$26-50$ & Good water quality \\
$51-75$ & Poor water quality \\
$76-100$ & Very Poor water quality \\
$>100$ & Unsuitable water quality \\
\hline
\end{tabular}

The result of base-exchange indices showed that all samples of pre-monsoon seasons belong to $\mathrm{Na}^{+}-\mathrm{HCO}_{3}^{-}$type having $\mathrm{r}_{1}$ value $>1$ and most of the samples of the post-monsoon period except one belong to $\mathrm{Na}^{+}-\mathrm{SO}_{4}{ }^{2-}$ type, $\mathrm{r}_{1}$ value is $<1$ (Figure 3). $\mathrm{Na}^{+}-\mathrm{HCO}_{3}^{-}$type water indicates the water is belonging to the industrial area, while $\mathrm{Na}^{+}-\mathrm{SO}_{4}{ }^{2-}$ type shows water sample is of marine origin and belongs from nearby coastline areas. ${ }^{37}$ Meteoric genesis index $r_{2}$ can be used 
to determine the sources of groundwater samples are deep meteoric water percolation type or shallow meteoric water percolation type. Where $r_{2}<1$, the sources of groundwater are of deep meteoric water percolation type if, $r_{2}>1$ it shows the sources of groundwater is shallow meteoric water percolation type. Meteoric genesis index $r_{2}$ can be computed by using Eq. 2.

$$
r_{2}=\left(\mathrm{K}^{+}+\mathrm{Na}^{+}\right)-\mathrm{Cl}^{-} / \mathrm{SO}_{4}^{2-} \mathrm{meq} / \mathrm{l}
$$

Table 5 Water quality index and water quality rating for drinking purpose of all samples of both seasons

\begin{tabular}{lllll}
\hline Sample No. & WQI for Pre-monsoon samples & WQI rating & WQI for post-monsoon samples & $\begin{array}{l}\text { WQI } \\
\text { rating }\end{array}$ \\
\hline $\mathrm{N}-1$ & 99.33446 & Very Poor & 84.10185 & Very Poor \\
$\mathrm{N}-2$ & 113.1126 & Unsuitable & 97.41986 & Very Poor \\
$\mathrm{N}-3$ & 94.09373 & Very Poor & 93.48763 & Very Poor \\
$\mathrm{N}-4$ & 98.49496 & Very Poor & 83.64454 & Very Poor \\
$\mathrm{N}-5$ & 104.8226 & Unsuitable & 79.21547 & Very Poor \\
$\mathrm{N}-6$ & 66.79304 & Poor & 75.61379 & Poor \\
$\mathrm{N}-7$ & 105.5694 & Unsuitable & 121.5685 & Unsuitable \\
$\mathrm{N}-8$ & 103.1378 & Unsuitable & 109.0722 & Unsuitable \\
$\mathrm{N}-9$ & 99.23593 & Very Poor & 127.2823 & Unsuitable \\
$\mathrm{N}-10$ & 103.6824 & Unsuitable & 93.96128 & Very Poor \\
$\mathrm{N}-11$ & 98.08827 & Very Poor & 89.53767 & Very Poor \\
$\mathrm{N}-12$ & 97.97031 & Very Poor & 89.1806 & Very Poor \\
$\mathrm{N}-13$ & 102.1454 & Unsuitable & 93.2903 & Very Poor \\
$\mathrm{N}-14$ & 101.7176 & Unsuitable & 92.0119 & Very Poor \\
\hline
\end{tabular}
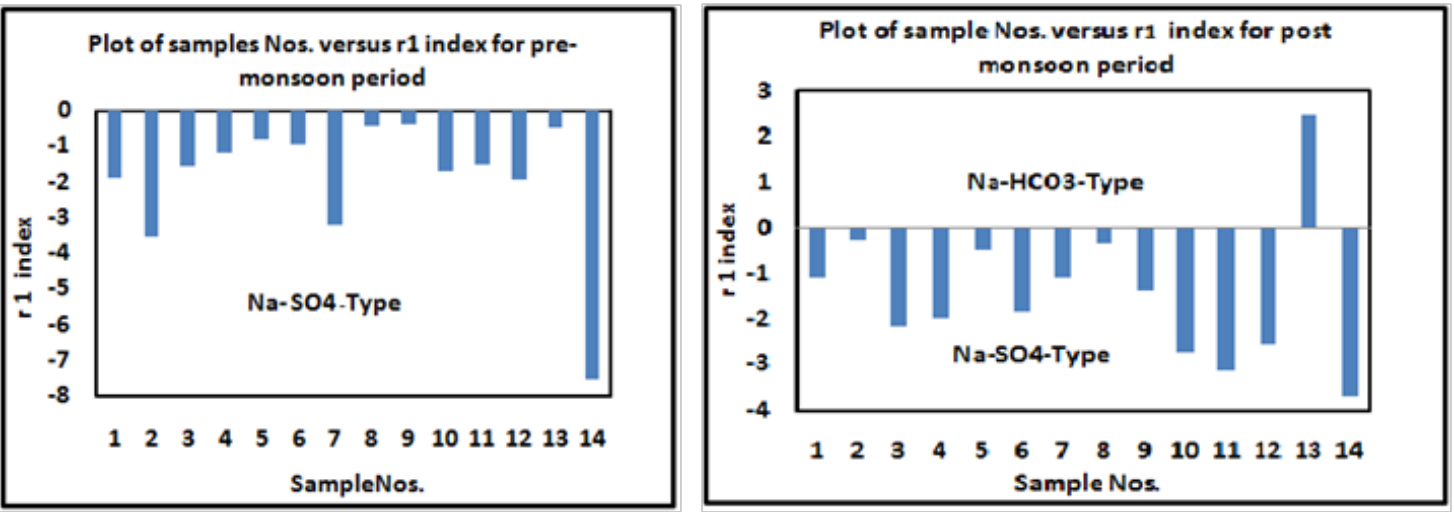

Figure 3 Base-exchange indices $\left(r_{1}\right)$ for pre and post-monsoon ground water samples of studied area.

Results of these calculations confirmed that $100 \%$ samples of pre-monsoon season have deep meteoric water percolation type groundwater sources and except one, the all samples of post-monsoon period belong to deep meteoric water percolation type (Figure 4). Hydrogeochemical water classification using modified piper diagram (Chadha diagram) the classification for hydrogeochemical facies of water in terms of milliequivalent percentage differences between milliequivalent per liter of total dissolve alkaline earth and alkali metals $(\mathrm{Ca}+\mathrm{Mg})-(\mathrm{Na}+\mathrm{K}) \%$, and between milliequivalent per liter of total dissolve weak acidic anions and strong acidic anions $\left(\mathrm{CO}_{3}+\mathrm{HCO}_{3}\right)-\left(\mathrm{Cl}-\mathrm{SO}_{4}\right) \%$, was done by using modified Piper diagram (Chadha diagram). Modified Piper diagram (Chadha diagram) is modified version of Piper diagram ${ }^{38}$ and expended Durov diagram ${ }^{39}$ to predict the source of pollution in water. Modified piper diagram is useful to illustrate the geochemical evolution of groundwater by evaluating the chemical relationships among water type and milliequivalent percentage difference of dissolved major-ions on the basis of the position of data within the field of $\mathrm{X}-\mathrm{Y}$ coordinate. According to Chadha diagram, the rectangular field of the plot can be divided into eight sub-fields. The results show that majority of the sample in pre-monsoon period belongs to the fifth group which indicates that $\mathrm{Ca}+\mathrm{Mg}$ and $\mathrm{CO}_{3}+\mathrm{HCO}_{3}$ exceed $\mathrm{Na}+\mathrm{K}$ and $\mathrm{Cl}-\mathrm{SO}_{4}$ resultant temporary hardness was obtained in sample water (Figure $5 \mathrm{~A})$. Whereas, $65 \%$ sample of post-monsoon period belongs to group sixth, while $25 \%$ samples fall in $5^{\text {th }}$ group (Figure $5 \mathrm{~B}$ ). It suggested that $\mathrm{Na}+\mathrm{K}$ and $\mathrm{Cl}-\mathrm{SO}_{4}$ ions concentration dominate over $\mathrm{Ca}+\mathrm{Mg}$ and $\mathrm{CO}_{3}+\mathrm{HCO}_{3}$ in post-monsoon period samples. 

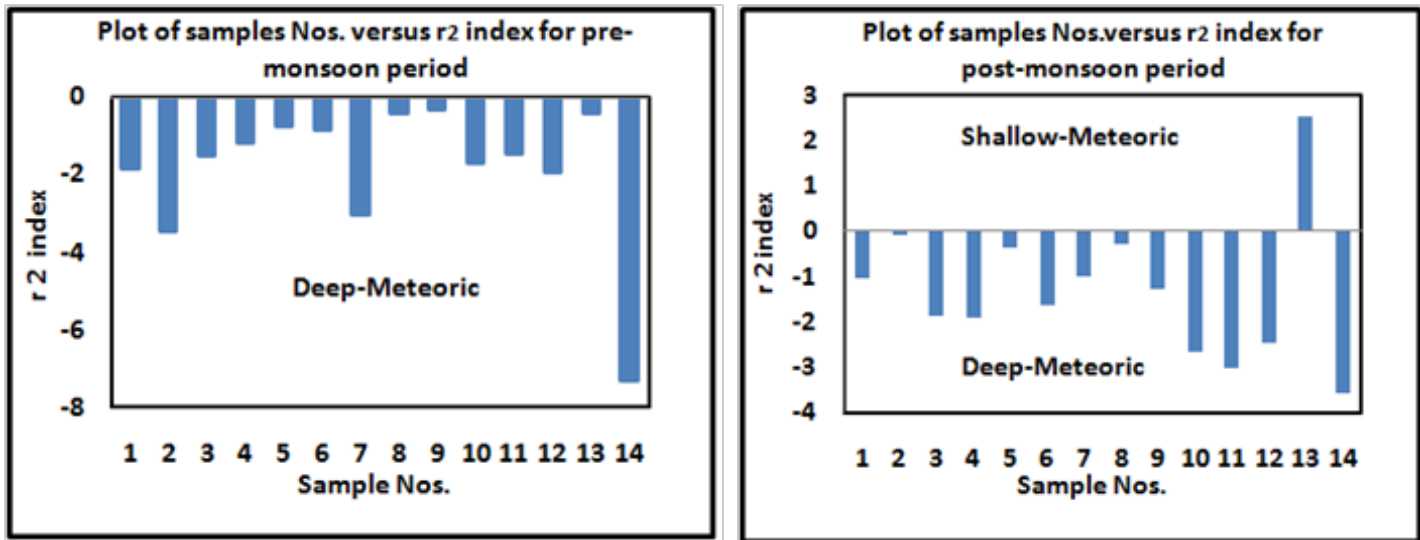

Figure 4 Meteoric genesis indices $\left(r_{2}\right)$ for pre and post-monsoon ground water samples of studied area.
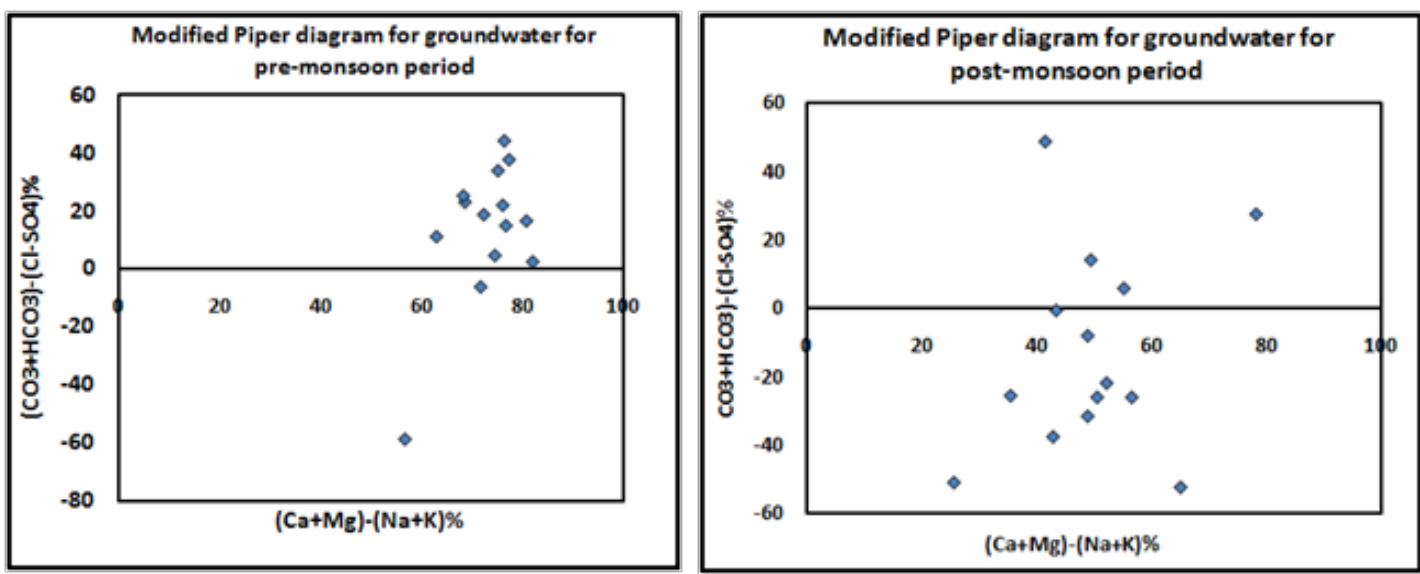

Figure 5 Plot of modified piper diagram (Chadha diagram) for groundwater for pre and post-monsoon period.

\section{Gibbs plots}

Gibbs plot could reveal information on the mechanisms and processes which influence the geochemistry of water. Gibbs plot is used to determine the relationship between groundwater chemistry and lithological characteristics of the host rock or rock-water interaction. Gibbs ratio-I in which TDS versus $\mathrm{Na}^{+}+\mathrm{K}^{2+} /\left(\mathrm{Na}^{+}+\mathrm{K}^{2+}+\mathrm{Ca}^{2+}\right)$ is plotted for cations and TDS versus $\mathrm{Cl}^{-} /\left(\mathrm{Cl}^{-}+\mathrm{HCO}_{3}^{-}\right)$for anions

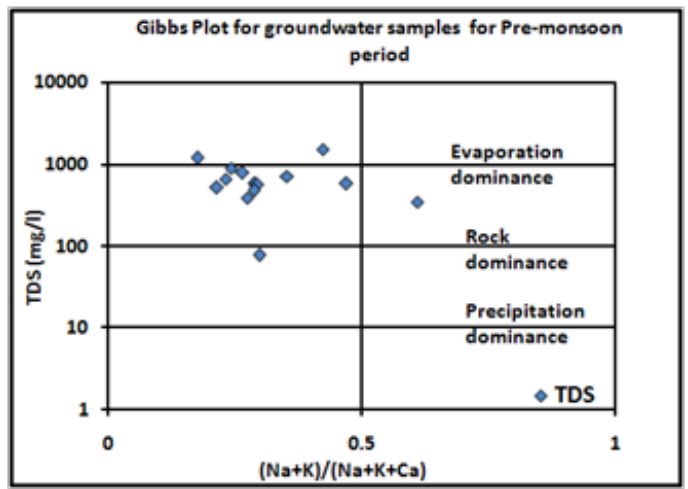

Figure 6 Gibbs plots for groundwater samples for pre-monsoon seasons.

\section{Chloro-alkaline indices}

The CAIs is used to understand the changes in chemical composition of groundwater due to ion-exchange between groundwater, and it's in Gibbs ratio-II. ${ }^{40}$ This plot is categorized into three distinct fields on the basis of the position of data in the plotted area are evaporation dominance, rock dominance and precipitation dominance. ${ }^{41}$ The results of Gibbs ratio-I and Gibbs ratio-II are represented that all water samples of both seasons belong to evaporation dominance (Figure 6) (Figure 7). It demonstrates that evaporation is a major controlling factor which influencing groundwater quality through inducing the chemical weathering of host rocks of the study area.

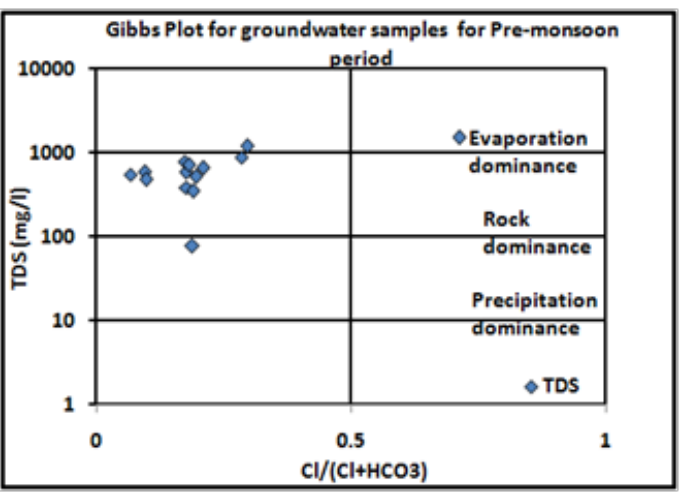

sub-surface flow path through which it is circulated. The Chloroalkaline indices can be evaluated by the formulae mentioned below (ions expressed in meq/l). ${ }^{42}$ 


$$
\begin{aligned}
& C A I-I=(\mathrm{Cl}-\mathrm{Na}+\mathrm{K}) / \mathrm{Cl} \\
& \mathrm{CAI}-\mathrm{II}=(\mathrm{Cl}-\mathrm{Na}+\mathrm{K}) /\left(\mathrm{SO}_{4}+\mathrm{CO}_{3}+\mathrm{HCO}_{3}+\mathrm{NO}_{3}\right)
\end{aligned}
$$

According to this formula, the ion-exchange process is classified into two equilibrium conditions are chloro-alkaline equilibrium and chloro-alkaline disequilibrium condition. Data analysis results of pre-monsoon and post-monsoon sample except one sample shows positive CAI indices ratio (Figure 8). The positive ratio is known as a base-exchange reaction, and resulting condition is called as chloroalkaline equilibrium, whereas the negative ratio of ion-exchange is known as cation-anion exchange reaction and shows chloro-alkaline disequilibrium condition. ${ }^{43}$ Data points along the aquiline in the plots of $\mathrm{Ca}+\mathrm{Mg}$ versus $\mathrm{SO}_{4}+\mathrm{HCO}_{3}(\mathrm{meq} / \mathrm{l})$ for both seasons suggest carbonate weathering is a dominant phenomenon in the studied area. Figures show that most of the samples of pre-monsoon and $72 \%$ post-monsoon sample are affected by carbonate weathering while remaining by silicate weathering (Figure 9).
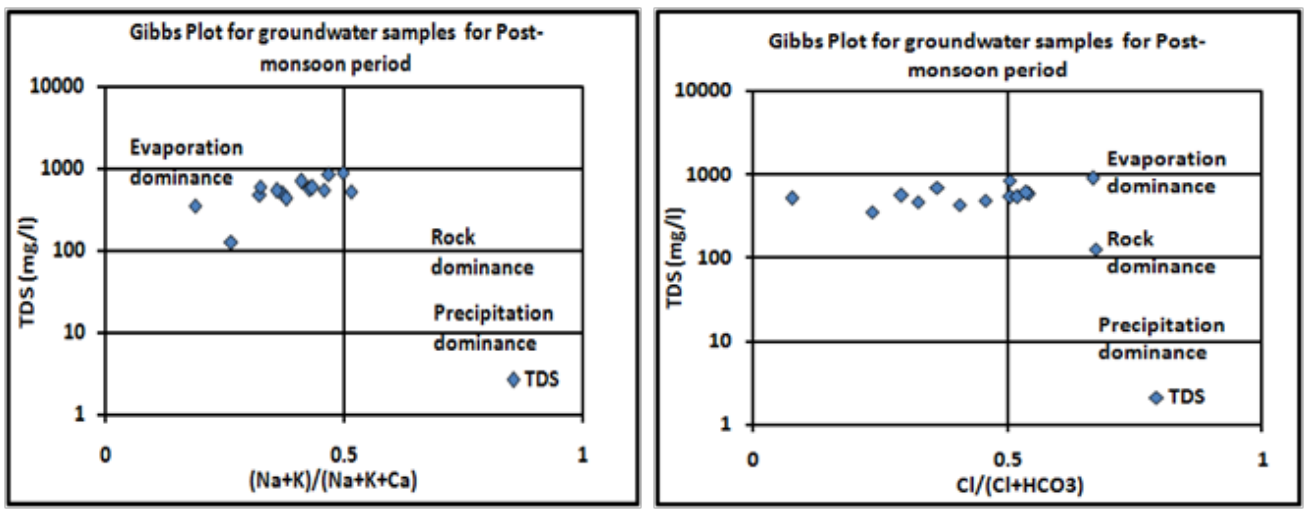

Figure 7 Gibbs plots for groundwater samples for post-monsoon seasons.
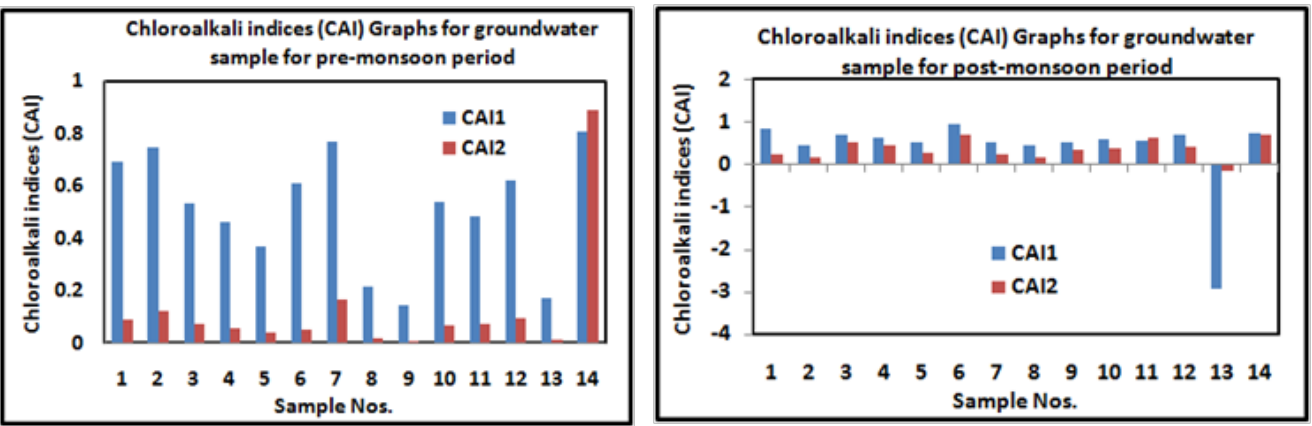

Figure 8 Plot of chloroalkali indices (CAl) for groundwater samples for pre and post-monsoon seasons.
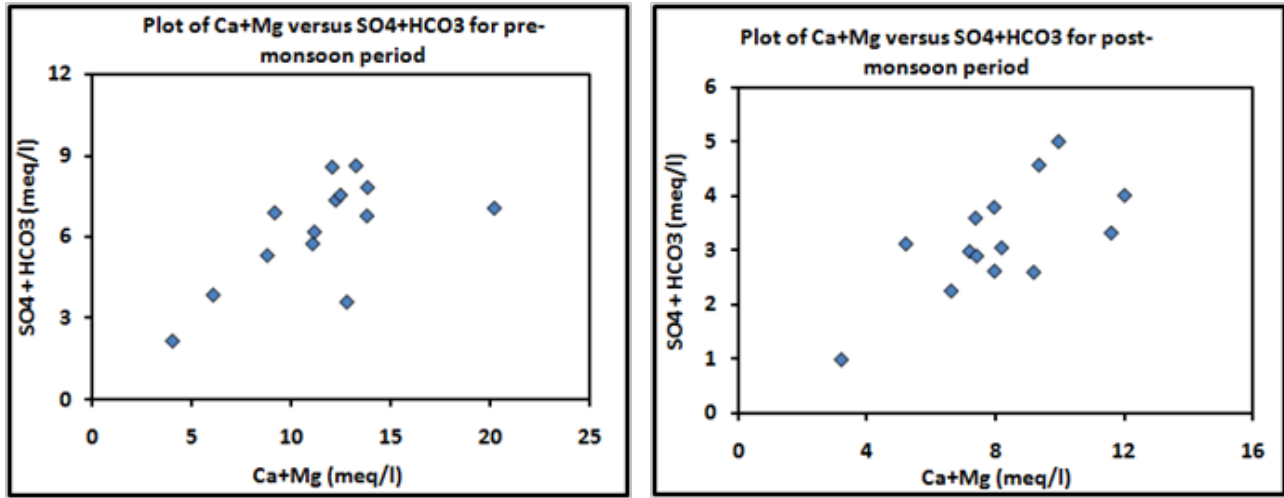

Figure 9 Plot of $\mathrm{Ca}+\mathrm{Mg}(\mathrm{meq} / \mathrm{l})$ ratio versus $\mathrm{SO}_{4}+\mathrm{HCO}_{3}(\mathrm{meq} / \mathrm{l})$ for groundwater samples for pre and post-monsoon period.

\section{Kelly's ratio}

Kelly's ratio is used to determine the suitability of water for irrigation purpose on the basis of the concentration of sodium ion against calcium and magnesium ions. Kelly's ratio (KR) computed by the formula ${ }^{44,45}$ as given below: (all ionic concentration is expressed in $\mathrm{meq} / \mathrm{l})$.

$$
K R=\frac{\mathrm{Na}^{+}}{\left(\mathrm{Ca}^{2+}+\mathrm{Mg}^{2+}\right)}
$$

Elevated sodium ion concentration is one of the prime concerns which causes salinity hazard in water and make it unsuitable for 
irrigation purpose. Based on Kelly's ratio groundwater is classified into suitable, marginal and unsuitable if $\mathrm{KR}$ is $<1, \mathrm{KR}$ is $1-2$, and $\mathrm{KR}$ is $>2$ respectively. All samples of both seasons are reported as suitable for irrigation has KR level less than 1 (Tables 6-9).

Table 6 Classification of groundwater quality for irrigation purpose based on $\mathrm{KR}$ values

\begin{tabular}{llll}
\hline $\begin{array}{l}\text { Kr value } \\
(\mathbf{m e q} / \mathbf{l})\end{array}$ & Class & \multicolumn{2}{l}{ Samples falling in dissimilar seasons } \\
& & Pre-monsoon & Post-monsoon \\
\hline$<1$ & No. of samples $\mathrm{N}=14$ & No. of samples $\mathrm{N}=\mathrm{I4}$ \\
$>1$ & Unsafe & All Samples & All Samples \\
\hline
\end{tabular}

Table 7 Classification of groundwater based SAR values

\begin{tabular}{|c|c|c|c|}
\hline \multirow{3}{*}{$\begin{array}{l}\text { SAR } \\
\text { value } \\
\text { (meq/I) }\end{array}$} & \multirow{3}{*}{ Class } & \multicolumn{2}{|c|}{ Samples falling in dissimilar seasons } \\
\hline & & Pre-monsoon & Post-monsoon \\
\hline & & $\begin{array}{l}\text { No. of samples } \\
N=14\end{array}$ & $\begin{array}{l}\text { No. of samples } \\
N=14\end{array}$ \\
\hline$<10$ & Excellent & All samples & All samples \\
\hline I8-Oct & Good & Nil & Nil \\
\hline $18-26$ & Fair & Nil & Nil \\
\hline$>26$ & poor & Nil & Nil \\
\hline
\end{tabular}

\section{Sodium absorption ratio}

It is a significant parameter to determine the suitability of groundwater for irrigation purpose. It can be estimated by employing equation:

$$
S A R=\frac{\mathrm{Na}^{+}}{\sqrt{\frac{1}{2}}\left(\mathrm{Ca}^{2+}+\mathrm{Mg}^{2+}\right)}
$$

Water having the excess sodium absorption ratio $>26$ produces the undesirable effect on chemical composition of water, soil structure and reducing soil permeability by replacing absorbed calcium and magnesium ${ }^{46}$ The SAR values of pre-monsoon and post-monsoon seasons is founded $<10$. Hence, the water of study region can be graded as excellent for irrigation use (Table 7-9). In the equation sodium, calcium, and magnesium concentrations are expressed in $\mathrm{meq} / \mathrm{l}$.

\section{Residual sodium carbonate}

The presence of excess bicarbonate and carbonate ion concentration indicates water hardness and makes it unsuitable for agricultural purpose. RSC index $<1$ can be preferred as suitable for irrigation. It should not be $>2$ for irrigation water. Data analysis shows that values RSC index of studied water samples falls in the safe category and suitable for irrigation. The equation for calculating the Residual sodium carbonate (RSC) index is:

$$
\mathrm{RSC} \text { index }=\left[\mathrm{HCO}_{3}+\mathrm{CO}_{3}\right]-[\mathrm{Ca}+\mathrm{Mg}] \mathrm{meq} / \mathrm{l}
$$

According to RSC index groundwater for the agricultural purposes can be classified into three classes are suitable, where RSC is $<1$, marginal if RSC value between 1-2 and greater than 2 is graded as unsuitable (Table 8) (Table9).

Table 8 Classification of groundwater based on RSC values

\begin{tabular}{llll}
\hline \multirow{2}{*}{$\begin{array}{l}\text { RSC } \\
\text { value } \\
(\text { meq/I) }\end{array}$} & Class & \multicolumn{2}{l}{ Samples falling in dissimilar seasons } \\
\cline { 3 - 4 } & & $\begin{array}{l}\text { Pre-monsoon } \\
\text { No. of samples } \\
\mathbf{N}=14\end{array}$ & \multicolumn{1}{l}{$\begin{array}{l}\text { Post-monsoon } \\
\mathbf{N}=\text { I4 }\end{array}$} \\
\hline$<1.25$ & Safe & All samples & All samples \\
I.25 -2.5 & Marginal & Nil & Nil \\
$>2.5$ & Unsuitable & Nil & Nil \\
\hline
\end{tabular}

\begin{tabular}{|c|c|c|c|c|c|c|}
\hline \multirow{2}{*}{ Sample no. } & \multicolumn{3}{|c|}{ Pre-monsoon } & \multicolumn{3}{|c|}{ Post-monsoon } \\
\hline & KR (meq/l) & SAR (meq/l) & $\operatorname{RSC}(\mathrm{meq} / \mathrm{l})$ & KR (meq/l) & SAR (meq/l) & $\operatorname{RSC}(\mathrm{meq} / \mathrm{l})$ \\
\hline $\mathrm{N}-\mathrm{I}$ & 0.1 & 0.46 & -6.26 & 0.11 & 0.34 & -2.14 \\
\hline $\mathrm{N}-2$ & 0.09 & 0.59 & -14.23 & 0.32 & 1.39 & -4.83 \\
\hline $\mathrm{N}-3$ & 0.18 & 0.77 & -3.27 & 0.31 & 1.32 & -6.86 \\
\hline $\mathrm{N}-4$ & 0.16 & 0.66 & -4.39 & 0.31 & 1.17 & -4.57 \\
\hline$N-5$ & 0.22 & 0.75 & -3.07 & 0.33 & 1.2 & -4.4 \\
\hline $\mathrm{N}-6$ & 0.13 & 0.37 & -2.82 & 0.15 & 0.38 & -2.68 \\
\hline$N-7$ & 0.13 & 0.68 & -8.09 & 0.38 & 1.7 & -5.14 \\
\hline $\mathrm{N}-8$ & 0.12 & 0.62 & -5.59 & 0.28 & 1.08 & -4.63 \\
\hline N-9 & 0.12 & 0.6 & -4.38 & 0.46 & 1.87 & -5.4 \\
\hline $\mathrm{N}-10$ & 0.13 & 0.69 & -7.07 & 0.32 & 1.58 & -8.59 \\
\hline $\mathrm{N}-\mathrm{II}$ & 0.18 & 0.95 & -5.6 & 0.58 & 2.8 & -8.93 \\
\hline $\mathrm{N}-12$ & 0.13 & 0.61 & -5.96 & 0.27 & 1.07 & -5.6 \\
\hline $\mathrm{N}-13$ & 0.14 & 0.68 & -5.83 & 0.4 & 1.61 & -4.43 \\
\hline $\mathrm{N}-14$ & 0.26 & 1.29 & -10.59 & 0.38 & $\mathrm{I} .47$ & -4.45 \\
\hline
\end{tabular}

Table 9 Calculated parameters indexes of groundwater for irrigation quality

Citation: Priyanka M,Venkata RG, Ratnakar D. Groundwater quality appraisal and its hydrochemical characterization in and around Iron ore mine, Chitradurga, Karnataka. Int J Hydro. 20I7; I (5):I5I-I6I. DOI: I0.15406/ijh.2017.01.00029 


\section{Conclusion}

The groundwater quality analyses results indicate the groundwater around the M/s. A. Narrain Iron Ore Mines Chitradurga, Karnataka region is slightly alkaline and hard water. Results have revealed that the majority of samples have high Total Dissolved Solids value than permissible limit which make it unsuitable for the drinking purpose. The results of Base-exchange indices $\left(r_{1}\right)$ and $\left(r_{2}\right)$ and major divalent cations $\left(\mathrm{Ca}^{2+}\right.$ and $\left.\mathrm{Mg}^{2+}\right)$ concentration has confirmed that sources of samples is deep meteoric percolation type which was common in semi-arid to arid region. Results of other standard classification methods are SAR, RSC and KR, Piper diagram, Gibbs plot and Chloro-alkali indices (CAI-I and CAI-II) showed that sample water is suitable for domestic as well as agricultural purpose. Furthermore, Result of all comparison study and water quality index are shown that water samples of the studied region are not fit for drinking. Groundwater samples have very high amount of sulphate, nitrate, and divalent cations. An elevated amount of nitrate ion in the sample water is indicated the presence of organic matter in the samples due to drainage of domestic effluent in the nearby area. Presence of very high concentrations of carbonates, oxides of divalent cations and sulphate indicates the exploitation of limestone, and pyrite, magnesite, silicates, and calcite minerals, and banded iron ore. Based on results it is found that exploration and processing of minerals caused moderate adverse impact on groundwater quality of iron ore mine area due to climatic conditions and improper management of mining area. ${ }^{47-53}$

\section{Acknowledgments}

Authors are thankful to the Director, CSIR-NGRI, Hyderabad, for his kind permission to publish this manuscript. Authors are thankful to Sri Krishna Kulkarni AGM (HSE) M/s Vedanta Limited for initiation of the study and his detailed discussions throughout the study.

\section{Conflict of interest}

Authors declare there is no conflict of interest in publishing the article.

\section{References}

1. Domenico PA, Schwartz FW. Physical and chemical hydrogeology. Wiley, USA; 1990. p. 1-824.

2. Edmunds WM, Guendouz A, Mamou A, et al. Groundwater evolution in the Continental Intercalative aquifer of southern Algeria and Tunisia: trace element and isotopic indicators. J Appl Geochem. 2003;18:805-822.

3. Kumar SK, Rammohan V, Sahayam JD, et al. Assessment of groundwater quality and hydrogeochemistry of Manimuktha river basin, Tamil Nadu, India. Environ Monit Assess. 2009;159(1-4):341-351.

4. WHO. Guidelines for drinking water quality. 2nd edn, World Health Organization, USA; 1993. p. 1-188.

5. BIS. Indian Standard Drinking Water Specification IS: 10500. Bureau of Indian Standards, India; 1991. p. 1-11.

6. Catling LA, Abubakar I, Lake IR, et al. A systematic review of analytical observational studies investigating the association between cardiovascular disease and drinking water hardness. Water Health. 2008;6(4):433-442.

7. Rylander R, Bonevik H, Rubenowitz E. Magnesium and calcium in drinking water and cardiovascular mortality. Scand Work Environ Health. 1991.17(2):91-94.

8. Shivran HS, Dinesh K. Improvement of water quality through biological identification. J Environ Sci Eng. 2006;48(1):57-60.
9. Ministry of Mines Indian Bureau of Mines. Indian Minerals Year Book: state review. 51th edn, Ministry of Mines and Indian Bureau of Mines Government of India, India; 2012.

10. Henke K. Arsenic in natural environments. In: Henke KR (Ed.), Arsenic: environmental chemistry, health threats and waste treatment. 1st edn, Wiley, UK; 2009. p. 69-235.

11. Nessner KV, Esposito E. Biotechnological strategies applied to the deconta-mination of soils polluted with heavy metals. Biotechnol Adv. 2010;28(1):61-69.

12. Lucassen E, Smolders AJP, Roelofs JGM. Increased groundwater levels cause iron toxicity in Glyceria fluitans(L). Aquatic Botany. 2000;66(4):321-327.

13. Ma FJ, Ryan PR, Delhaize E. Aluminum tolerance in plants and the complexing role of organic acids. Trends in Plant Science. 2001;6(6):273-278.

14. Fan TT, Wang YJ, Li CB, et al. Effect of organic matter on Sorption of $\mathrm{Zn}$ on Soil: Elucidation by Wien Effect Measurements and EXAFS Spectroscopy. Environ Sci Tech. 2016;50(6):2931-2937.

15. Sami K. Recharge mechanisms and geochemical processes in a semi-arid sedimentary basin, Eastern Cape, South Africa. Journal of Hydrology. 1992;139(1-4):27-48.

16. Skrzypek G, Shawan D, Pauline F. Geochemical and hydrological processes controlling groundwater salinity of a large inland wetland of northwest Australia. Chemical Geology. 2013;357:164-177.

17. Adams S, Titus R, Pietersen K, et al. Hydrochemical characteristics of aquifers near Sutherland in the Western Karoo, South Africa. Journal of Hydrology. 2001;241(1-2): 91-103.

18. Djabri L, Rouabhia A, Hani A, et al. Origin of water salinity in a lake and coastal aquifer system. Environ Geol. 2007;54(3):565-573.

19. Trabelsi R, Kacem A, Zouari K, et al. Quantifying regional groundwater flow between Continental Intercalaire and Djeffara aquifers in southern Tunisia using isotope methods. Environmental Geology. 2009;58(1):171-183.

20. Rouabhia A, Baali F, Fehdi $\mathrm{CH}$, et al. Hydrochemical and isotopic investigation of a sandstone aquifer groundwater in a semiarid region, El Ma El Abiod, Algeria. Environ Geol. 2009;57(8):1699-1705.

21. Fehdi $\mathrm{CH}$, Aek Rouabhia, Baali F, et al. The hydrogeochemical characterization of Morsott-El Aouinet aquifer, Northeastern Algeria. Environ Geol. 2009;58(7):1611-1620.

22. Domenico PA.Concepts and models in groundwater hydrology. McGrawHill Book Co, USA; 1972. p. 1-416.

23. Schuh WM, Klinekebiel DL, Gardner JC, et al.Tracer and nitrate movements to groundwater in the Norruem Great Plains. J Environ Qual. 1997;26:335-1347.

24. Toth $\mathrm{J}$. The role of regional gravity flow in the chemical and thermal evolution of groundwater. In: Proceedings of the first Canadian/American conference on hydrogeology, Banff, Alta. 1984.

25. Singh K, Hundal HS, Singh D. Geochemistry and assessment of hydrogeochemical processes in groundwater in the southern part of Bathinda district of Punjab, Northwest India. Environ Earth Sci. 2011.64(7):1823-1833.

26. CGWB. Groundwater information booklet, Chitradurga district Karnataka. Central ground water board, India; 2013. p. 1-31.

27. APHA. Standard methods for the examination of water and wastewater. 19th edn, American Public Health, USA; 1998. p. 1-541.

28. WHO. Guidelines for drinking water quality. World Health Organization, Geneva for Drinking-water Quality, USA; 2008. p. 1-668. 
29. SASO. Unbottled drinking water (SASO 701). Saudi Arabian Standard Organization, Saudi Arabia; 2000.

30. United States Environmental protection Agency. Guideline for Water Reuse. 2012

31. Tyagi S, Sharma B, Prashant S, et al. Water quality assessment in term Of Water Quality Index. 2013;1(3):34-38.

32. CCME. Canadian water quality guidelines for the protection of aquatic life. Canadian Council of Ministers of the Environment, Canada; 2001. p. $1-5$.

33. Horton RK. An index number system for rating water quality. Journal of water pollution Cont Fed. 1965;3:300-305.

34. Ramkrishnaiah CR, Sadashivaiah C, Ranganna G. Assessment of water quality index of for the groundwater in Tumkur Taluk, Karnataka State, India. E-Journal of Chem. 2009;6(2):1-8.

35. Bhuven T, Macwan JEM, Soni Chirag K. Assessment of water quality index of a small lake in south Gujrat region, India, ISEM-2011 Thailand $2011 ; 1-3$.

36. Soltan ME. Evaluation of groundwater quality in Dakhla Oasis (Egyptian Western Desert). Environ Monit Assess. 1999;57(2):157-168.

37. Bokhari YA, Khan MZA. Deterministic Modelling of AI-Madinah AIMunawarah Groundwater Quality Using Lumped Parameter Approach KAU Earth Science. 1992;5:89-107.

38. Chadha DK. A proposed new diagram for geochemical classification of natural water and interpretation of chemical data. Hydrogeology Journal. 1999; 7(5):431-439.

39. Durov SA. Natural waters and graphic representation of their compositions. Dokl Akad Nauk SSSR. 1948;59:87-90.

40. Elango L, Kannan R. Rock-water interaction and its control on chemical composition of groundwater. Developments in Environmental Science. 2007;5:229-243.

41. Gibbs RJ. Mechanisms controlling world water chemistry. Science. 1970;17(3962):1088-1090.
42. Schoeller H. Geochemistry of groundwater: An international guide for research and practice Book, UN ESCO, India; 1965. p. 1-18.

43. Aghazadeh N, Mogaddam A A. Investigation of hydrochemical characteristics of groundwater in the Harzandat aquifer, Northwest of Iran. Environ Monit Assess. 2011;176(1-4):183-195.

44. Kelly WP. Permissible composition and concentration of irrigation waters. Proceedings of the American Society of Civil Engineers. 1946;66:607-613.

45. Kelly WP. Use of saline irrigation water. Soil Science 1963;95(6):385-391.

46. Richards LA. Diagnosis and improvement of saline-alkali soils, Agriculture. Handbook, US Department of Agriculture, USA; 1954. p. $1-166$.

47. Annual weather report of Karnataka Agricultural Department, India 2017.

48. Guler C, Thyne GD. Hydrologic and geologic factors controlling surface and groundwater chemistry in Indian Wells-Owens Valley area, southeastern California, USA. J Hydrogeol. 2014;285:177-198.

49. Han D, Liang X, Jin M, et al. Hydrogeochemical indicators of groundwater flow systems in the Yangwu River. In: Alluvial Fan, Xinzhou Basin, Shanxi, editors. China. Environ Manage 2009;44(2):243-255.

50. Kumar S, Ratnakanth MJ, Hanumantha $\mathrm{CH}$. Assessment and Mapping of Ground Water Quality Using Geographical Information System. International Journal of Engineering Science and Technology. 2010;2(11):6035-6046.

51. Risacher F, Alonso H, Salazar C. The origin of brines and salts in Chilean salars: A hydrochemical review. Earth Sci Rev. 2013;63(3-4):249-293.

52. Shiv KG, Kumar N. Groundwater contamination in coal mining areas: A critical review. International Journal of Engineering and Applied Science. 2016;3(2):1-6

53. Vengosh A, Kloppmann W, Marie A, et al. Sources of salinity and boron in the Gaza Strip: natural contaminant flow in the southern Mediterranean Coastal aquifer. Water resource research. 2005;41(1). 